\title{
How to wreck your own presentation: Twelve tips to confuse an audience
}

\author{
by Stephen Wyatt ${ }^{1,3}$ and Nelson Thiffault ${ }^{2,3}$
}

\begin{abstract}
Increasingly, professional foresters are expected to participate in communication and consultation processes to present specialised knowledge to non-foresters. However, forest management is increasingly complex; forestry is too important to be left in the hands of those who do not understand its intricacies. In this tongue-in-cheek paper, we provide professional foresters with twelve easy-to-use tips to ensure that presentations to non-foresters remain hermetic, confuse the public and preserve the exclusivity of our professional competence. Forging an unclear message, finding a bad title, and failing to adjust to listeners are just the first steps to success in boring an audience. Over-confidence in technical gadgets and an over-powering use of presentation backgrounds, fonts, and special effects will add to the confusion. Furthermore, efforts should be made to conceal the key message by hiding the big picture, maximizing the quantity of information, and using slides that no one will remember. Jargon is highly effective and should be used wherever possible. The speaker should treat the audience as an amorphous crowd, avoiding contact with individuals and dodging questions. We finally suggest using the last slide as an ultimate weapon to ensure that everyone leaves the room more confused than when they arrived. We hope that these simple tips will help professional foresters across Canada to make the most of opportunities for presentations, thereby reinforcing the correct role of the public in forestry.
\end{abstract}

Key words: presentation, communication, public consultation

\section{RÉSUMÉ}

Les professionnels forestiers sont de plus en plus sollicités pour participer activement aux processus de consultation. On leur demande de partager leur savoir technique avec un public non forestier. Or, l'aménagement forestier se complexifie; la foresterie est trop importante pour être laissée aux mains d'un public qui n'en comprend pas les subtilités. Dans cet article à caractère ironique, nous proposons aux professionnels forestiers douze astuces qui leur assureront que leurs présentations publiques demeureront hermétiques, qu'elles brouilleront la compréhension des auditoires, et qu’elles contribueront ainsi à préserver l'exclusivité de nos compétences professionnelles. Élaborer un message confus, choisir un mauvais titre et négliger d'ajuster le discours à l'auditoire ne sont que les premières étapes pour réussir à ennuyer le public. Une confiance exagérée envers les moyens techniques, couplée à une utilisation à outrance d'une diversité de fonds d'écran, de polices de caractères et d'effets spéciaux ajoutent à la confusion. De plus, des efforts doivent être mis pour dissimuler l'idée maîtresse, maximiser la quantité d'informations et concevoir des diapositives qui sont rapidement oubliées. L'utilisation du jargon est très efficace et doit être favorisée. Le conférencier doit considérer l'auditoire comme une foule anonyme, éviter les contacts visuels directs avec les individus, et esquiver les questions. Finalement, nous suggérons d'utiliser la dernière diapositive comme une occasion ultime d'embrouiller l'auditoire. Nous espérons que ces astuces simples aideront les forestiers du Canada à tirer le meilleur parti possible de leurs présentations et ainsi consolider le juste rôle du public en foresterie.

Mots clés : présentation, communication, consultation publique

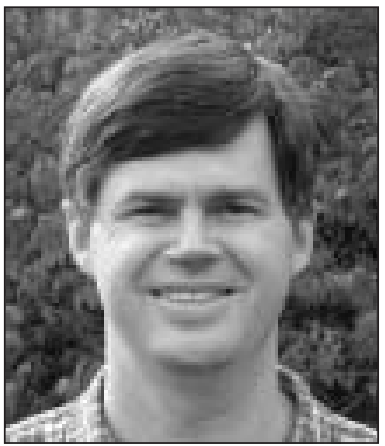

Stephen Wyatt

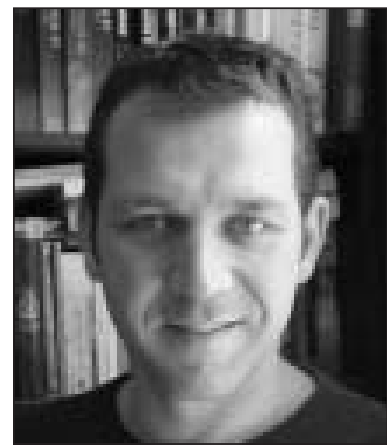

Nelson Thiffault

\section{Introduction}

Picture yourself. You are standing in front of a room full of people (perhaps 40, perhaps 240). You have been invited to provide a presentation of your current work and to explain its significance for forest management in your region. You are a professional forester with many years experience and, you must admit, an expert in this field. Your audience is composed of members of the public with little knowledge of forest management. Quite frankly, you have more important things to do with your time - and you wish that they did as well. Your goal is to finish this presentation as soon as possible so that you can return to your real work.

\footnotetext{
${ }^{1}$ Stephen Wyatt, Ph.D. Faculté de foresterie, Université de Moncton, campus d'Edmundston, 165 boul. Hébert, Edmundston, NouveauBrunswick, E3V 2S8. swyatt@umce.ca (corresponding author)

${ }^{2}$ Nelson Thiffault, Ingénieur forestier, Ph.D.

${ }^{3}$ Neither author is a specialist in communications. We are rank amateurs - just like you.
} 
Increasingly, foresters are required to present information about forest management to non-foresters. Requirements for public consultation in Ontario, presentations to government inquiries in Québec and New Brunswick, negotiations with First Nations in British Columbia and Alberta and certification processes everywhere all expect that foresters can communicate their specialised knowledge of forests to those who have few skills and little experience in the field. The Canadian Institute of Forestry / Institut forestier du Canada itself has called for professional foresters to become more involved in public communication (McLaughlan 2005).

We believe that this is a dangerous trend. Forest management is an increasingly complex field and forestry knowledge is too important to be left in the hands of those who have not been trained to understand its intricacies. Our objective is to provide professional foresters with tips to ensure that their presentations will not be understood by audiences. This will contribute to shorter consultation and certification processes throughout the country as the public looses any interest it might have in forest management. Students should find our tips useful to avoid getting good marks for class presentations, thereby better preparing them for future employment. For their part, most scientists probably know all these tips and are often very experienced in their application. For you as a professional forester, these tips should help ensure that you are never again invited to make a presentation.

\section{The Tips}

\section{You don't need a message}

Your understanding of your own message is an important starting point for a presentation. If you are uncertain about what you want to say, then the audience will probably find your presentation confusing and unconvincing. Discussing the topic with a colleague is a waste of time for both of you (unless you can dump the job). You don't need to know your subject or to have a clear and concise message. As long as you know a little more than the audience, you can bluff your way through almost anything.

\section{Choose a bad title}

The title is your first chance to reduce interest in your presentation. With a little effort, you can find a title that is both accurate and quite unintelligible. A good trick is to start with "The effects of...," or "The impacts of..." In fact, if you are able to put the word "of" as the second or third word of your title, chances are that your title is at bad as it can be ${ }^{4}$. An original title could bring more people to your talk, which is obviously not what you want.

\section{Address the wrong audience}

The audience is there to listen to you. You do not need to adapt your speech to their interests, their concerns or their existing knowledge of the subject. You are the expert and you have a responsibility to provide accurate and complete information. If they do not understand, that is their problem, not yours.

\footnotetext{
${ }^{4}$ Our planned title for this paper was "A series of characteristics contributing to the obfuscitation of non-technical audiences during obligatory participation processes." We were told to change it.
}

\section{Have confidence in the organizer, the software, the projec-} tion system and anything else

You are the speaker and you do not need to make sure that your presentation will run properly. Arrive just a few minutes before your scheduled time so that you can avoid any lastminute changes by the organizer. Don't worry about testing your presentation on the computer; if something goes wrong, you will get the credit, not the poor technician who will be trying to fix things up. It is your name on the program and the audience is looking at you rather than the organizer. Each technical problem will enhance your reputation as a bad speaker, reduce audience numbers for your presentations and help make sure that you are not invited again.

\section{Make the most out of presentation software}

Today's software offers numerous possibilities for turning your speech into a show. Use as many of these as you can in a single presentation, or even in a single slide. "Moderation in all things" is a cliché that should not apply.

\section{Background and font - lots or none at all}

Careful selection of background and font can help people to follow a presentation and to understand key ideas. You can also use it to bedazzle the audience; in fact black text on a white background can be both literally blinding and mind-numbingly dull. Alternatively, continual changes of background and an endless variety of lettering will help to confuse the audience and hide the significance of the information you are presenting. Small print (anything less than 20 point) enables you to put more information on a slide while simultaneously reducing readability.

\section{Bells and whistles}

Graphics that sing and dance and text that flies in from outer space will distract the audience from what you are saying $^{5}$. Long video sequences and hyperlinks to obscure Web sites will fill in time in your presentation and increase the probability of the computer stopping half-way through. Your audience will remember the special effects rather than the information on the slides.

\section{Be mysterious - don't let your audience see the big picture}

Beginning a speech with an introduction or an overview of your presentation helps the audience to organize and understand the information as it comes. Ignoring this step and diving straight into the real stuff enables you to lose half your audience without any effort. If you must show a plan of your presentation, use a mapping slide with a long list of bullet points including "Introduction" and "Conclusion" (Fig. 1).

\section{7. "Snow" your audience by maximizing the quantity of information}

Presenting as much information as possible will quickly overload your audience. Copying entire paragraphs from your most recent report is useful. You can also add large tables with lots of columns, lines and numbers; graphs with hundreds of points and a dozen trend lines; or complicated flowchart dia-

\footnotetext{
${ }^{5}$ A personal favourite is the "Random effects" option for the appearance of text. It adds a certain mystery to a presentation if no one, including the speaker, knows where the next idea is coming from.
} 


\section{OUR PRESENTATION}

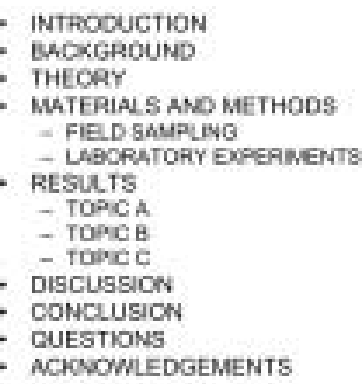

Fig. 1. With this type of mapping slide, you'll make sure that people will not remember anything. Note the deliberate use of capital letters to render the boring content difficult to read.

grams. If you have lots of numbers say "don't look at the numbers, they are not important." If some numbers (or words or trend lines) are important, make sure that they are drowned in an ocean of data.

\section{8. "See and forget" slides for numbing your audience}

A "see and forget" slide is used to show important information in a way that no one will remember. The quantity of information is one way of doing this, but there are many others; lists of bullet points, single words that have meaning for you but not for the audience, generalities and beautiful photos. Avoid using images and words together to present a clear concise message or to establish the theme for each part of your presentation. The mapping slides in Fig. 1 and 2 describe the same presentation in quite different ways.

\section{Use technically explicit language and terminology (jargon)}

A general definition of jargon is the use of specialized expressions or delineations, unnecessarily complicated, indigenous to a particular field, and unintelligible to those outside the group that uses it. Using gobbledygook on your slides and in your speech will help conceal your real message. For example, if you wish to tell an audience of woodlot owners how you concluded that one planting technique was better than another, we suggest something along the lines of: "We used a Fisher's protected LSD test to separate treatment means in the case of a significant $p$-value after the F-test of the ANOVA" (Thiffault et al. 2003).

\section{Address an "audience," not individuals}

The people sitting there are just an audience for you; they are almost irrelevant to your presentation. You do not need to make eye-contact with them, to recognise their level of interest or to watch for signs of confusion or uncertainty about your information. Treat them as an anonymous amorphous crowd, not as individuals.
We describe a research project and its

potential impacts on forest plantations in

your region

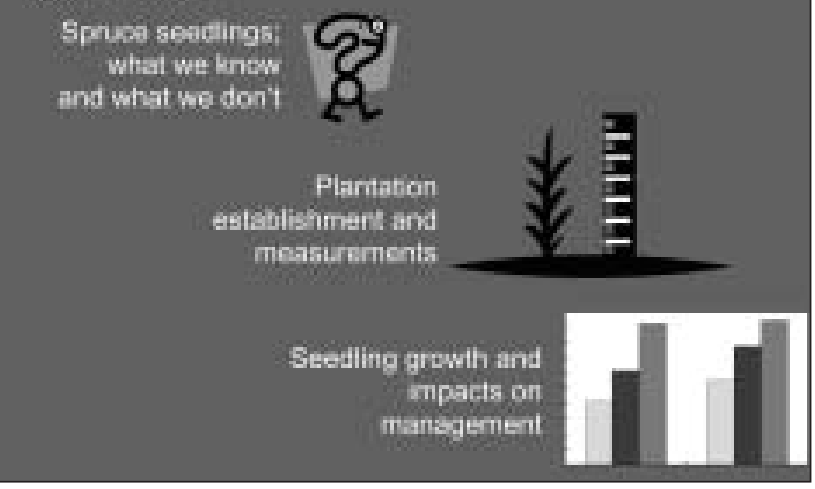

Fig. 2. A mapping slide that will guide your audience through your presentation and help them to follow your line of thought. Is this really what you want?

\section{Avoid questions}

The audience will try to use questions to clarify everything that they did not understand and to find ways of applying your information to their own situation. You do not want this, so it is important to avoid questions. Firstly, make sure that your presentation is longer than the time allowed in the program. If the moderator asks you to stop, or even turns off the microphone, just continue talking loudly. You can often use the question period like an annexe, providing highly detailed information that you could not include in the presentation itself. Don't worry if your answer is not related to the question. If you must respond to a question, treat the person with disdain and imply that the answer is clear and they should have understood this. These techniques will discourage other people from asking further questions.

\section{Confusion as the take-home message}

Most people remember one or two key points from a presentation, so you should prepare to leave them with a single message. Your last slide will probably stay on the screen while you avoid questions. If this slide is a concise conclusion, then this is what people will remember. However, most presentations finish with a slide saying "Thank-you" or "Questions." Our personal favourite is a huge question mark filling up the entire screen. If people leave your presentation more confused than they were when they arrived, you have done your job well.

\section{Conclusion}

Being - and most of all staying - a bad speaker is continuous and hard work. Don't pay critical attention to the techniques used by other speakers to present their information. Analyzing other presentations and trying to understand what made a particular talk interesting may lead you to question your own style (and our tips). From time to time, a wellmeaning colleague may even try to point out weaknesses or 
strengths in your presentations with the aim of helping you communicate with the public. Such people are not only questioning your competence as a forester, they are also undermining the exclusivity of our profession.

There are many books aimed at helping people become more professional in their presentations. Our personal list of books to avoid includes the following subversive titles:

- The Craft of Scientific Presentations by Michael Alley (2003)

- How to Write and Publish a Scientific Paper by Robert A. Day (1998)

- Writing and Presenting Scientific Papers by Birgitta Malmfors, Phil Garnsworthy and Michael Grossman (2000)

There are many other books on the market, so be careful. A quick Google search with keywords such as "power presentations" or "good presenter" will help you identify further tools that could undermine your skills as a bad speaker.

Forestry is important. The future of forests requires an increasingly higher standard of forest management. It requires a better understanding of forests and a detailed knowledge of what happens there. Professional foresters are the guardians of this knowledge, are trained to understand the nuances and the implications of such knowledge, and are able to apply it in ways that will enable better forest management. Specialist forestry knowledge should not be diluted and corrupted in order to make it appealing to an uninformed public. We hope that these simple tips will help professional foresters across Canada to make the most of opportunities for presentations and reinforce the correct role of the public in forestry.

\section{Acknowledgements}

We trust that all readers understand that this article is tonguein-cheek; doing the exact opposite of all we suggest here is certainly an effective start to making a good presentation. We have nobody in particular to acknowledge, other than all the speakers - good and bad - who have appeared in front of us over the years and who have inspired this paper.

\section{References}

Alley, M. 2003. The Craft of Scientific Presentations. Springer, New York, NY. 241 p.

Day, R.A. 1998. How to Write \& Publish a Scientific Paper, $5^{\text {th }}$ ed. Oryx Press, Westport, CT. 275 p.

McLaughlan, M. 2005. Perspective: Are forestry professionals reluctant communicators? The Forestry Chronicle 81(1): 6 .

Malmfors, B., P. Garnsworthy and M. Grossman. 2000. Writing and Presenting Scientific Papers. Nottingham University Press, Nottingham, UK. 133 p.

Thiffault, N., R. Jobidon and A.D. Munson. 2003. Performance and physiology of large containerized and bare-root spruce seedlings in relation to scarification and competition in Québec (Canada). Annals of Forest Science 60: 645-655. 